\title{
Effect of epidermal growth factor-like peptides on pig cumulus cell expansion, oocyte maturation, and acquisition of developmental competence in vitro: comparison with gonadotropins
}

\author{
Radek Procházka, Michal Petlach, Eva Nagyová and Lucie Němcová \\ Institute of Animal Physiology and Genetics, Academy of Sciences of the Czech Republic, Rumburska 89, \\ 27721 Liběchov, Czech Republic
}

Correspondence should be addressed to R Procházka; Email: prochazka@iapg.cas.cz

\begin{abstract}
The aim of this work was to assess the FSH-stimulated expression of epidermal growth factor (EGF)-like peptides in cultured cumulusoocyte complexes (COCs) and to find out the effect of the peptides on cumulus expansion, oocyte maturation, and acquisition of developmental competence in vitro. FSH promptly stimulated expression of amphiregulin (AREG) and epiregulin (EREG), but not betacellulin (BTC) in the cultured COCs. Expression of $A R E G$ and EREG reached maximum at 2 or $4 \mathrm{~h}$ after FSH addition respectively. FSH also significantly stimulated expression of expansion-related genes (PTGS2, TNFAIP6, and HAS2) in the COCs at 4 and 8 h of culture, with a significant decrease at $20 \mathrm{~h}$ of culture. Both AREG and EREG also increased expression of the expansion-related genes; however, the relative abundance of mRNA for each gene was much lower than in the FSH-stimulated COCs. In contrast to FSH, AREG and EREG neither stimulated expression of CYP11A1 in the COCs nor an increase in progesterone production by cumulus cells. AREG and EREG stimulated maturation of oocytes and expansion of cumulus cells, although the percentage of oocytes that had reached metaphase II was significantly lower when compared to FSH-induced maturation. Nevertheless, significantly more oocytes stimulated with AREG and/or EREG developed to blastocyst stage after parthenogenetic activation when compared to oocytes stimulated with FSH alone or combinations of FSH/LH or pregnant mares serum gonadotrophin/human chorionic gonadotrophin. We conclude that EGF-like peptides do not mimic all effects of FSH on the cultured COCs; nevertheless, they yield oocytes with superior developmental competence.

Reproduction (2011) 141 425-435
\end{abstract}

\section{Introduction}

FSH and $\mathrm{LH}$ are important regulators of granulosa cell proliferation, differentiation, and steroidogenesis. In mammalian ovarian follicles, $\mathrm{FSH} / \mathrm{LH}$ signaling is essential for follicle growth, secretion of follicular fluid (FF), and steroidogenesis. Preovulatory surge of $\mathrm{LH}$ results in the resumption of meiosis in oocytes, expansion of surrounding cumulus cells, and ovulation of matured cumulus-oocyte complex (COC) into oviduct. Recent data indicate that these $\mathrm{LH}$-induced events are mediated in preovulatory follicles by several members of epidermal growth factor (EGF)-like protein family. Experiments on mice revealed that $\mathrm{LH}$ binds to its receptor on mural granulosa cells and induces expression of amphiregulin (AREG), epiregulin (EREG), and betacellulin (BTC; Park et al. 2004, Ashkenazi et al. 2005). By autocrine and paracrine mechanisms, these EGF-like peptides induce expression of prostaglandin-endoperoxide synthase 2 (PTGS2) in both mural granulosa and cumulus cells, which leads to increased production of prostaglandin $\mathrm{E}_{2}\left(\mathrm{PGE}_{2}\right)$. $\mathrm{PGE}_{2}$ binds to its receptor on cumulus cells, activates MAPK14, and consequently stimulates production of AREG and EREG in cumulus cells. These peptides then bind to EGF receptor (EGFR) on cumulus cells and in the autocrine manner, via MAPK3/1 (also known as ERK1/2) stimulate transcription of genes involved in regulation of meiotic resumption and cumulus expansion (Shimada et al. 2006). The production of EGF-like peptides can also be induced by $\mathrm{FSH}$ in isolated COCs (Downs \& Chen 2008).

In rodent follicular cultures, the EGF-like peptides promoted both resumption of meiosis and cumulus expansion, preceded by an increased expression of the genes involved in the production of hyaluronic acid and its organization in extracellular matrix, as hyaluronan synthase 2 (HAS2), PTGS2, and tumor necrosis factor $\alpha$-induced protein 6 (TNFAIP6; Park et al. 2004, Ashkenazi et al. 2005). In a simplified model of COCs culture, each of the EGF-like peptides produced cumulus 
expansion and induced germinal vesicle breakdown (GVBD) when spontaneous maturation was inhibited by hypoxanthine (Park et al. 2004). The action of EGF-like peptides was inhibited by AG 1478, an EGFR kinase inhibitor (Park et al. 2004), and by metalloprotease inhibitors galardin (Ashkenazi et al. 2005) and Tapi2 (Yamashita et al. 2007). This indicates that the EGF-like peptides are produced as membrane-bound propeptides that, after shedding by metalloproteases, use the EGFR for signaling.

In a recent study, however, EREG was found to be a poor inducer of mouse cumulus expansion, oocyte maturation, and follicle luteinization when used as a sole stimulator in the follicular culture, but was as efficient as human chorionic gonadotrophin (hCG)/EGF when used as a meiotic stimulator for the isolated COCs (Romero \& Smitz 2009). Thus, it is not clear whether the EGF-like peptides can completely substitute for gonadotropins in stimulating oocyte maturation in vitro.

We have shown in previous papers that the EGFR signaling plays an important role in the regulation of meiosis in the pig (Prochazka et al. 2000, 2003). The aim of this work was to answer the question of whether EGF-like peptides can substitute for gonadotropins in stimulation of cumulus expansion, oocyte maturation, and acquisition of developmental competence in vitro or whether additional gonadotropin-induced signaling, besides the induction of the EGF-like peptides, is essential for occurrence of these events in pig COCs. For this reason, we studied the expression of EGF-like peptides in FSH-stimulated COCs and compared the effect of the peptides and $\mathrm{FSH}$ on expression of the expansion-related genes, activation of signaling pathways, and progesterone production in the COCs. In addition, we assessed the efficiency of EGF-like peptides and $\mathrm{FSH}$ in inducing maturation of oocytes, expansion of cumulus cells, and acquisition of the oocyte developmental competence.

\section{Results}

\section{Expression of EGF-like peptides in FSH-stimulated COCs}

FSH significantly stimulated expression of $A R E G$ and $E R E G$, but not of $B T C$ in cultured COCs. The expression of $A R E G$ and EREG reached maximum at 2 and $4 \mathrm{~h}$ after FSH addition respectively (Fig. 1). No further increase in AREG, EREG, and BTC expression was found beyond $4 \mathrm{~h}$ of culture in COCs, but the expression of EREG remained significantly increased up to $28 \mathrm{~h}$ of culture (data not shown). Since BTC does not seem to play a role in the regulation of COCs maturation in the pig, we further concentrated on functions of AREG and EREG in this process.
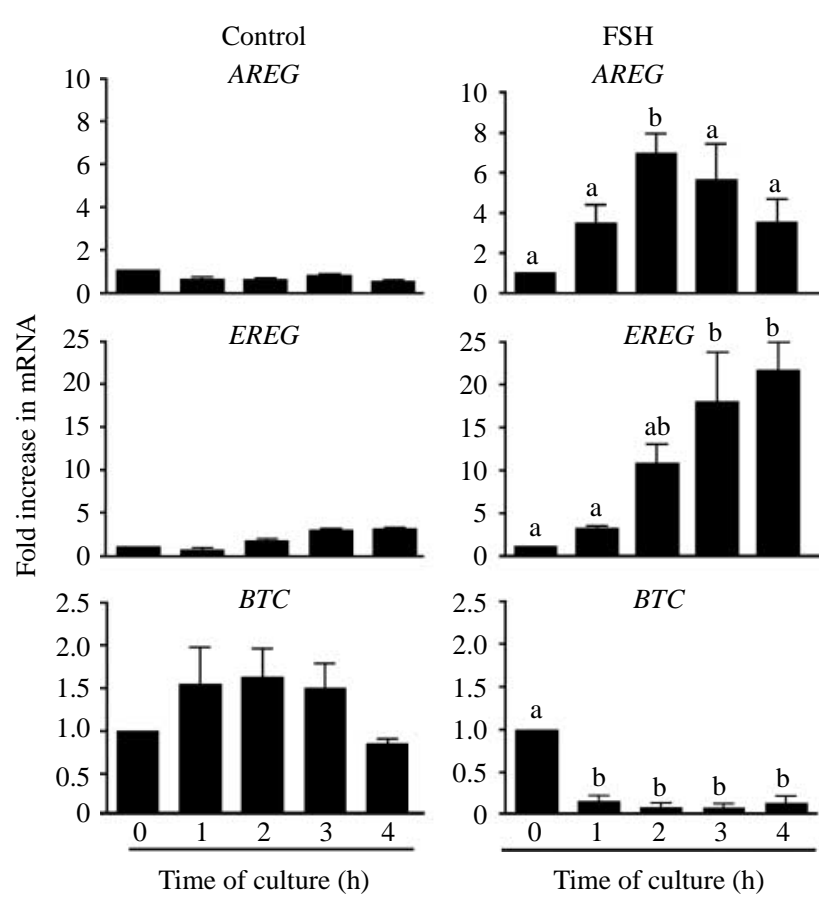

Figure 1 Expression of AREG, EREG, and BTC mRNA in COCs cultured in control or $\mathrm{FSH}$-supplemented medium. The relative abundance of specific gene mRNA is expressed in arbitrary units as fold strength increases in specific gene/ACTB ratio over the level found in COCs at the time $0 \mathrm{~h}$. Different superscripts or no common letters above the columns indicate significant differences $(P<0.05)$.

\section{Stimulation of oocyte maturation and cumulus cell expansion}

In control FF-supplemented medium without FSH or EGF-like peptides, $15.4 \pm 4.4 \%$ of oocytes underwent GVBD, and $32.5 \pm 4.0 \%$ of oocytes reached metaphase II (MII; Table 1). Addition of FSH to the culture medium resulted in a significant increase in proportion of oocytes reaching MII $(87.2 \pm 5.0 \% ; P<0.05)$ and a significant decrease in oocytes remaining in GV stage $(10.2 \pm 4.8 \%)$. In the groups stimulated with AREG, EREG, or both peptides together, more oocytes remained in GV stage $(30.5 \pm 4.7$ to $45.2 \pm 3 \% ; P<0.05)$, and fewer oocytes completed meiosis to MII stage (53.1 \pm 2.1 to $64.6 \pm 3.4 \% ; P<0.05)$ than in the $\mathrm{FSH}$ group. Nevertheless, the completion of meiosis was significantly higher in these groups than in the control group $(P<0.05)$. Maturation in the group of oocytes cultured with FSH and both EGF-like peptides was equal to the group of oocytes cultured with FSH alone. The expansion of cumulus cells was equally stimulated with either FSH or the EGF-like peptides (Table 1). Nevertheless, the course of expansion induced by AREG or EREG was faster than that induced by FSH. The COCs induced to expand by AREG or EREG reached maximum expansion at 20-24 h of culture and were mostly disorganized at the end of the culture period, losing cohesion between the oocyte and the cumulus cells, 
Table 1 Nuclear maturation and expansion of pig cumulus-oocyte complexes (COCs) cultured in medium supplemented with FSH and epidermal growth factor-like peptides for $42 \mathrm{~h}$.

\begin{tabular}{|c|c|c|c|c|c|}
\hline \multirow{2}{*}{$\begin{array}{l}\text { Type of culture } \\
\text { medium }\end{array}$} & \multirow{2}{*}{$\begin{array}{l}\text { Number } \\
\text { of COCs }\end{array}$} & \multicolumn{3}{|c|}{ Stage of oocyte nuclear maturation } & \multirow{2}{*}{$\begin{array}{c}\text { COCs with expansion } \\
3-4(\% \pm \text { S.E.M. })\end{array}$} \\
\hline & & GV (\% & GVBD (\% & MII (\% $\%$ S.E.M.) & \\
\hline Control & 97 & $55.3 \pm 3.9^{\mathrm{a}}$ & $15.4 \pm 4.4^{\mathrm{a}}$ & $32.5 \pm 4.0^{\mathrm{a}}$ & $0^{\mathrm{a}}$ \\
\hline $\mathrm{FSH}$ & 86 & $10.2 \pm 4.8^{\mathrm{b}}$ & $2.5 \pm 1.5^{\mathrm{bc}}$ & $87.2 \pm 5.0^{\mathrm{b}}$ & $69.5 \pm 4.6^{\mathrm{b}}$ \\
\hline AREG & 119 & $45.2 \pm 3.0^{\mathrm{a}}$ & $1.7 \pm 1.0^{\mathrm{bc}}$ & $53.1 \pm 2.1^{\mathrm{c}}$ & $55.8 \pm 6.8^{\mathrm{b}}$ \\
\hline EREG & 110 & $30.5 \pm 4.7^{\mathrm{c}}$ & $5.0 \pm 2.5^{\mathrm{ac}}$ & $64.6 \pm 3.4^{\mathrm{c}}$ & $56.0 \pm 6.1^{\mathrm{b}}$ \\
\hline AREG + EREG & 116 & $35.5 \pm 2.2^{\mathrm{c}}$ & $3.5 \pm 1.4^{\mathrm{ac}}$ & $61.0 \pm 2.5^{\mathrm{c}}$ & $51.9 \pm 6.0^{\mathrm{b}}$ \\
\hline $\mathrm{FSH}+\mathrm{AREG}+\mathrm{EREG}$ & 119 & $7.7 \pm 1.8^{\mathrm{b}}$ & $2.5 \pm 0.9^{\mathrm{b}}$ & $89.7 \pm 2.2^{\mathrm{b}}$ & $74.7 \pm 5.9^{\mathrm{b}}$ \\
\hline
\end{tabular}

Values with no common letter in superscripts within columns are significantly different $(P<0.05)$. GV, germinal vesicle; GVBD, germinal vesicle breakdown; MII, metaphase II. The data were summarized from four replicates.

whereas the COCs stimulated by FSH gradually enlarged the expansion area and remained well organized at $42 \mathrm{~h}$ of culture (Fig. 2).

\section{Expression of expansion-related genes and activation of signaling pathways}

FSH significantly stimulated the expression of PTGS2, TNFAIP6, and HAS2 at 4 and $8 \mathrm{~h}$ of culture, with a significant decrease at $20 \mathrm{~h}$ of culture. Both AREG and EREG also stimulated a prompt increase in the expression of the expansion-related genes, although the magnitude of the increase in expression of the mRNA for each gene was lower than in the FSH-stimulated COCs; the increase in EREG-induced TNFAIP6 was not significant. The dynamics of the expression was somewhat different for EREG-induced expression of HAS2 that persisted high at $20 \mathrm{~h}$ of culture (Fig. 3).

Activity of protein kinase A (PKA) and AKT kinase (also known as protein kinase $\mathrm{B}$ ) was assessed in the COCs 60 min after stimulation and activity of MAPK3/1 at $2 \mathrm{~h}$ after stimulation; the intervals were chosen on the basis of our previous results (Nemcova et al. 2007). FSH, AREG, and EREG promptly induced phosphorylation of MAPK3/1 and AKT kinase (Fig. 4A and B) over the level found in control COCs. As expected, FSH also efficiently activated the PKA (Fig. 4C). In contrast, AREG and EREG did not increase the activity of PKA at all (Fig. 4C). PKA activity was neither increased in the AREG- or EREG-stimulated COCs at 2, 4, and $6 \mathrm{~h}$ after stimulation (data not shown).

\section{Production of progesterone by COCs during culture in vitro}

In contrast to FSH, AREG and EREG did not stimulate the expression of CYP11A1 over the culture period of $20 \mathrm{~h}$ (Fig. 5A). Correspondingly, the production of progesterone by the COCs cultured with AREG or EREG remained low at the end of the period of culture (47.5 \pm 10.04 or $39.8 \pm 2.7 \mathrm{ng} / \mathrm{ml}$ respectively) and was not different from non-stimulated controls $(26.8 \pm 5.5 \mathrm{ng} / \mathrm{ml})$, whereas the COCs stimulated by FSH significantly $(P<0.001)$ increased the production of progesterone (326.6 $\pm 13.8 \mathrm{ng} / \mathrm{ml}$; Fig. 5B).

\section{Parthenogenetic development of oocytes}

Parthenogenetic development rather than IVF is now often used for the assessment of cytoplasmic maturation of cultured pig oocytes. This approach is justified by the fact that mammalian parthenogenetic or gynogenetic embryos undergo normal preimplantation development

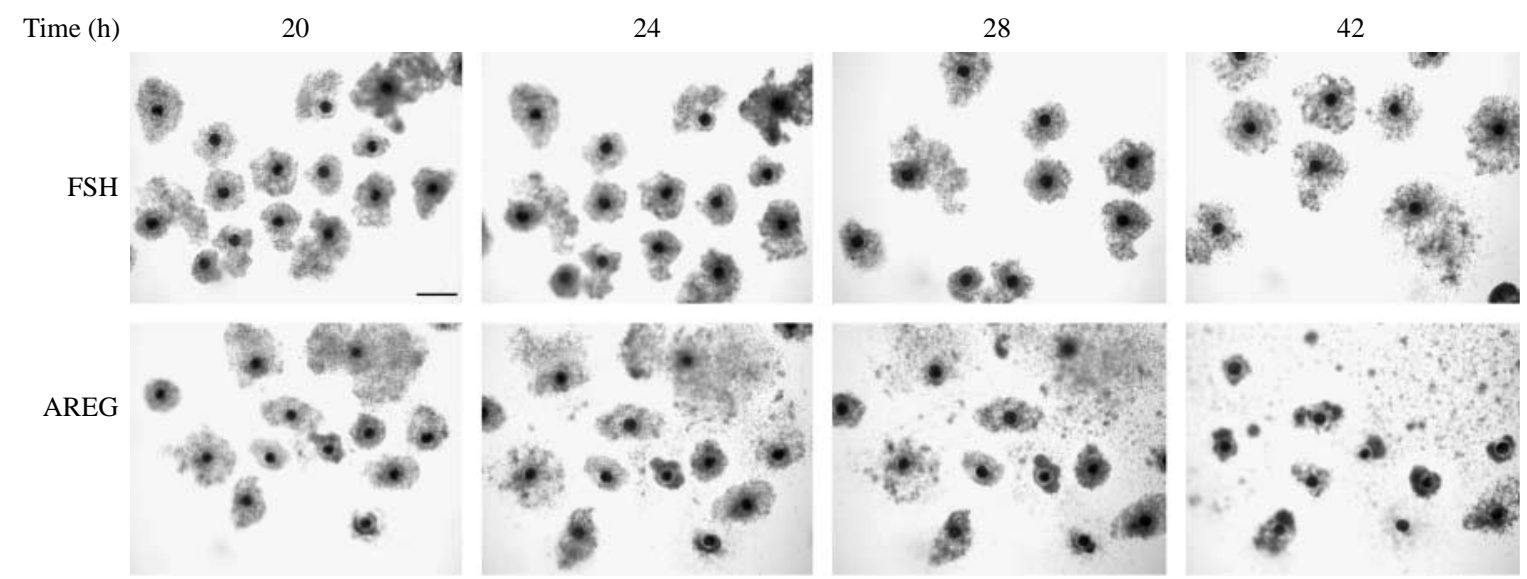

Figure 2 Expansion of COCs cultured in FSH- or AREG-supplemented medium. Bar $=400 \mu \mathrm{m}$. 

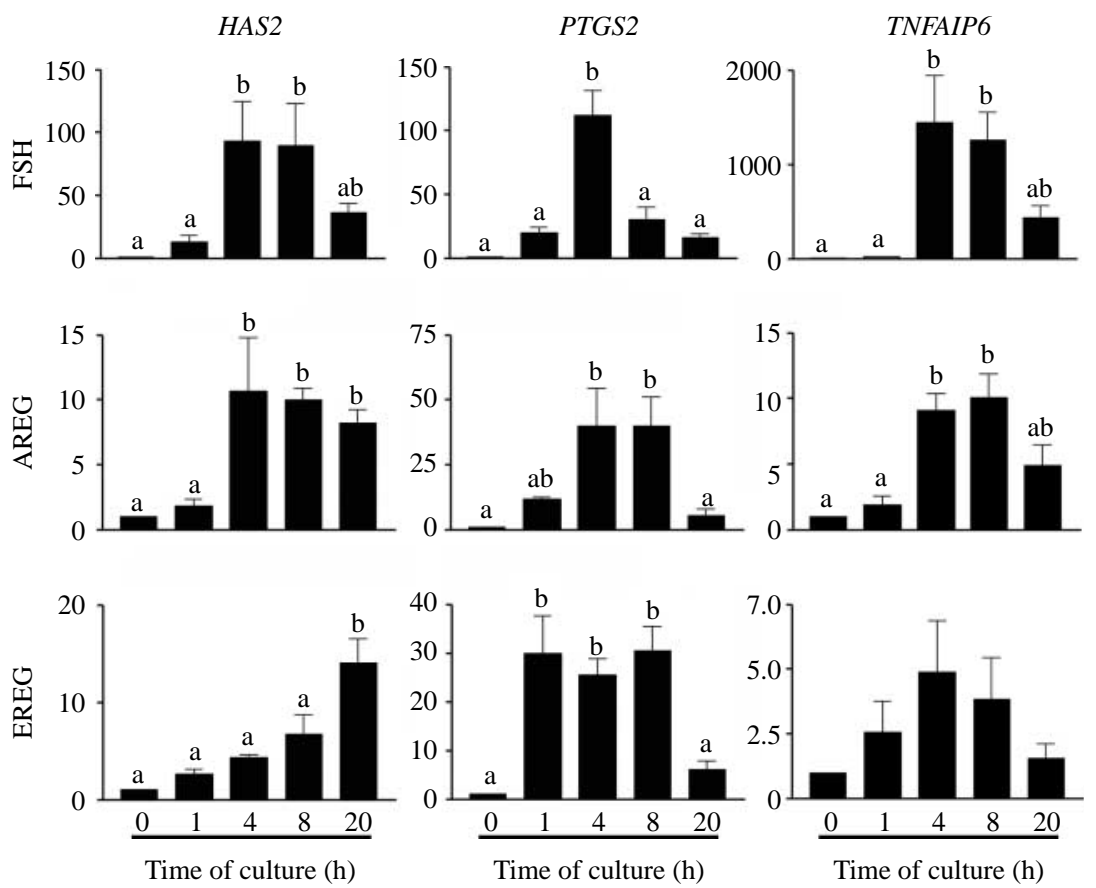

Figure 3 Expression of expansion-related genes (HAS2, PTGS2, and TNFAIP6) in COCs cultured in FSH-, AREG-, or EREG-supplemented medium. The relative abundance of specific gene mRNA is expressed in arbitrary units as fold strength increases in specific gene/ACTB ratio over the level found in COCs at the time $0 \mathrm{~h}$. Different superscripts or no common letters above the columns indicate significant differences $(P<0.05)$.

(Kaufman \& Gardner 1974, Surani \& Barton 1983), and avoids the problem with polyspermy associated with pig IVF in vitro. A combined treatment of matured oocytes with ionomycin and 6-diaminopurine (6-DMAP; Roh \& Hwang 2002) was used to stimulate parthenogenesis in our study.

The cleavage rate was higher in the groups of oocytes that had been cultured with FSH or FSH+AREG + EREG (Table 2), which corresponds to the higher maturation rate of oocytes in these groups compared to the groups of oocytes cultured with EGF-like peptides only (Table 1). However, the blastocyst rate was significantly higher in the groups of oocytes cultured with EGF-like peptides than with $\mathrm{FSH}$ alone. This indicates higher developmental potential of oocytes cultured with AREG and/or EREG than with FSH alone. This assumption was further strengthened by assessment of blastocyst rate among the cleaving parthenogenetic embryos when the blastocyst rate in the groups with AREG and/or EREG doubled the rate observed in the FSH group (Table 2). In addition, the number of nuclei in the blastocysts was significantly higher in all groups with EGF-like peptides than in the FSH group. It should be noted that combination of AREG and EREG was not any better in all of the followed aspects of parthenogenetic development than the action of either peptide alone. The combination of FSH and the EGF-like peptides significantly improved the FSH action but was not more efficient than the action of EGF-like peptides themselves.

$\mathrm{LH}$ alone is inefficient in stimulating maturation of freshly isolated pig COCs due to a lack of functional LH receptors (LHRs; Prochazka et al. 2009). However, functional LHR develops in pig COCs during the culture with FSH in vitro (Prochazka et al. 2009). For this reason,

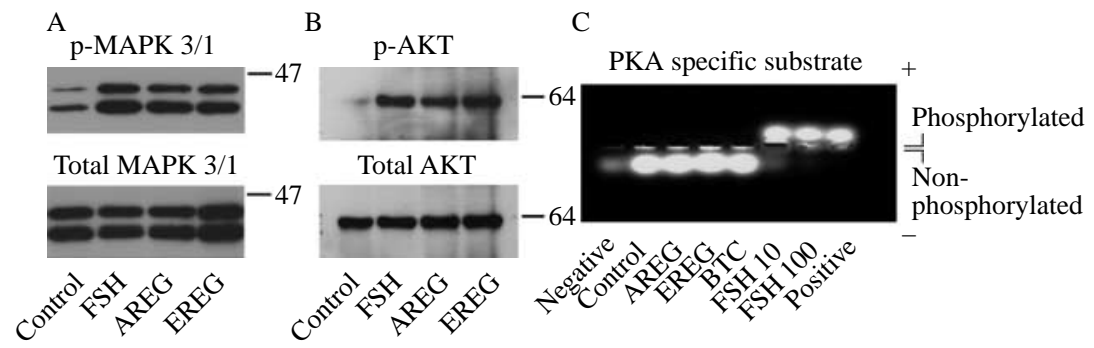

Figure 4 Effect of EGF-like peptides and FSH on activation of protein kinases in cultured COCs. The panels show representative results of three independent experiments. (A) Immunoblotting of phosphorylated (top panel) and total (bottom panel) MAPK3/1 in samples of COCs. (B) Immunoblotting of phosphorylated (top panel) and total (bottom panel) AKT in samples of COCs. (C) Effect of EGF-like peptides (AREG, EREG, and BTC; all $100 \mathrm{ng} / \mathrm{ml}$ ) and FSH (10 or $100 \mathrm{ng} / \mathrm{ml}$ ) on activation of PKA in cultured COCs. The panel displays migration of the phosphorylated (+) and non-phosphorylated (-) PKA-specific substrate in an electric field following the PKA assay. Negative (N) and positive (P) control assays were run without the cells or with 25 ng of catalytic subunit of PKA respectively. 

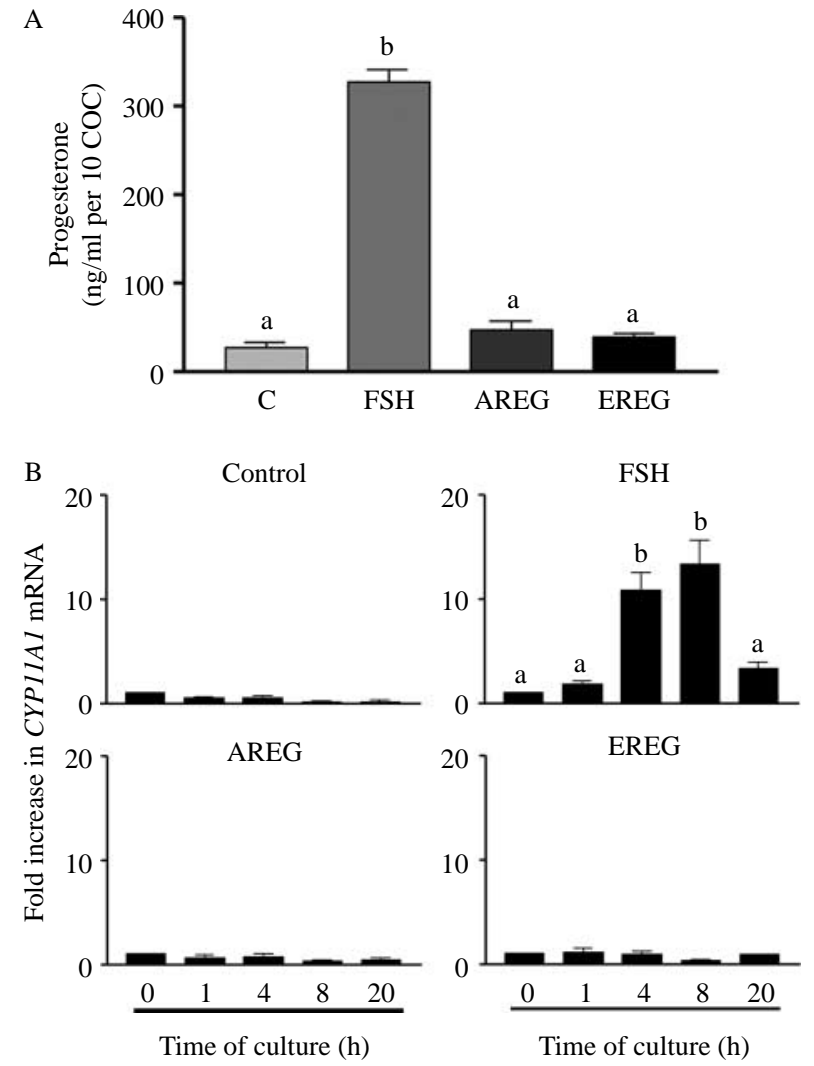

Figure 5 Effect of FSH, AREG, and EREG on expression of CYP11A1 and production of progesterone by cultured COCs. (A) Production of progesterone by COCs cultured for $44 \mathrm{~h}$ in control (C), FSH-, AREG-, and EREG-supplemented medium. Different superscripts above the columns indicate significant differences $(P<0.05)$. (B) Expression of $C Y P 11 A 1$ in cultured COCs. The relative abundance of specific gene mRNA was assessed by real-time RT-PCR and is expressed in arbitrary units as fold strength increases in specific gene/ACTB ratio over the level found in COCs at the time $0 \mathrm{~h}$. Different superscripts above the columns indicate significant differences $(P<0.05)$.

we have also compared developmental competence of pig COCs cultured with both gonadotropin hormones. As shown in Table 3, the COCs cultured with AREG reached significantly higher blastocyst rate among activated oocytes and cleaving parthenogenetic embryos than oocytes cultured with FSH, FSH+LH, or pregnant mares serum gonadotrophin (PMSG) +hCG. Also the mean number of nuclei was significantly higher in the AREG group than in the groups of oocytes cultured with any gonadotropin stimulation.

\section{Discussion}

In the mouse, the analysis of total ovarian mRNA by northern blotting revealed increased expression of $A R E G$, EREG, and BTC within 1-3 h after hCG application; AREG and $B T C$ expression was transient, but EREG expression persisted until $12 \mathrm{~h}$ after hCG (Park et al. 2004). In situ hybridization of mouse ovaries showed that the AREG, $E R E G$, and $B T C$ are detectable only in mural granulosa cells at $3 \mathrm{~h}$ after hCG (Park et al. 2004). However, an analysis of AREG, EREG, and BTC expression in mouse preovulatory follicles by semi-quantitative RT-PCR disclosed their enhanced expression not only in mural granulosa cells, but also in the COCs isolated from 4 to $12 \mathrm{~h}$ after hCG (Shimada et al. 2006). In in vitro cultured rat follicles stimulated with $\mathrm{LH}$, the expression of $A R E G$, EREG, and BTC peaked at $3 \mathrm{~h}$ of culture, but it was still significantly increased over the level found in nonstimulated control follicles at $9 \mathrm{~h}$ of culture (Ashkenazi et al. 2005). A prolonged expression of AREG and EREG (up to 10 and $40 \mathrm{~h}$ of culture respectively) was also found in pig-cultured COCs stimulated by gonadotropins (Yamashita et al. 2007). We have confirmed the prompt increase in AREG and EREG expression in $\mathrm{FSH}$-stimulated COCs. Moreover, the data of the present study indicate that $B T C$ is not increased following FSH stimulation. Expression of BTC was found only in rodent ovarian follicles and was not reported in studies dealing with the EGF-like peptide expression in the pig (Yamashita et al. 2007, Kawashima et al. 2008), horse (Lindbloom et al. 2008), macaque (Fru et al. 2007), and human (Freimann et al. 2004, Ben-Ami et al. 2006). Taken together, it is obvious that the gonadotropin-induced expression of EGF-like peptides in mural granulosa and consequently in cumulus cells is a common mechanism of intrafollicular signaling in preovulatory follicles. An autocrine stimulation of cumulus cells by EGF-like peptides thus plays an important role in the regulation of cumulus expansion and oocyte maturation. This makes a rationale for our next experiments assessing an effect of exogenous AREG and EREG on maturation of cultured pig COCs.

Table 2 Parthenogenetic development of pig oocytes cultured in medium with FSH and epidermal growth factor-like peptides.

\begin{tabular}{|c|c|c|c|c|c|}
\hline $\begin{array}{l}\text { Type of culture } \\
\text { medium }\end{array}$ & $\begin{array}{l}\text { Number of } \\
\text { activated oocytes }\end{array}$ & $\begin{array}{c}\text { Cleaving embryos } \\
(\% \pm \text { S.E.M. })\end{array}$ & $\begin{array}{c}\text { Blastocysts/activated } \\
\text { oocytes (\% } \% \text { S.E.M.) }\end{array}$ & $\begin{array}{l}\text { Blastocysts/cleaving } \\
\text { embryos }(\% \pm \text { S.E.M.) }\end{array}$ & $\begin{array}{c}\text { Mean number of } \\
\text { nuclei in blastocysts } \\
\text { (no. } \pm \text { S.E.M.) }\end{array}$ \\
\hline $\mathrm{FSH}$ & 166 & $81.4 \pm 3.0^{\mathrm{a}}$ & $17.3 \pm 1.9^{\mathrm{a}}$ & $21.4 \pm 2.7^{\mathrm{a}}$ & $22.7 \pm 1.3^{\mathrm{a}}$ \\
\hline AREG & 165 & $66.6 \pm 2.5^{\mathrm{bc}}$ & $30.9 \pm 3.0^{\mathrm{b}}$ & $44.2 \pm 1.5^{\mathrm{b}}$ & $30.1 \pm 1.4^{\mathrm{b}}$ \\
\hline EREG & 169 & $66.1 \pm 3.5^{\mathrm{bc}}$ & $28.9 \pm 3.0^{\mathrm{b}}$ & $44.2 \pm 4.5^{\mathrm{b}}$ & $29.1 \pm 1.3^{b}$ \\
\hline AREG＋EREG & 164 & $69.9 \pm 3.8^{\mathrm{ac}}$ & $30.3 \pm 3.3^{b}$ & $43.3 \pm 3.6^{\mathrm{b}}$ & $28.4 \pm 1.2^{\mathrm{b}}$ \\
\hline $\mathrm{FSH}+\mathrm{AREG}+\mathrm{EREG}$ & 168 & $82.7 \pm 3.7^{\mathrm{a}}$ & $31.9 \pm 1.9^{b}$ & $37.5 \pm 2.9^{b}$ & $28.1 \pm 1.1^{b}$ \\
\hline
\end{tabular}

Values with no common letter in superscripts within columns are significantly different $(P<0.05)$. Data were summarized from five replicates. 
Table 3 Parthenogenetic development of pig oocytes cultured in medium with gonadotropins or amphiregulin (AREG).

\begin{tabular}{lccccc}
\hline $\begin{array}{l}\text { Type of culture } \\
\text { medium }\end{array}$ & $\begin{array}{c}\text { Number of } \\
\text { activated oocytes }\end{array}$ & $\begin{array}{c}\text { Cleaving embryos } \\
(\% \pm \text { S.E.M.) }\end{array}$ & $\begin{array}{c}\text { Blastocysts/activated } \\
\text { oocytes } \% \pm \text { S.E.M.) }\end{array}$ & $\begin{array}{c}\text { Blastocysts/cleaving } \\
\text { embryos }(\% \pm \text { S.E.M.) }\end{array}$ & $\begin{array}{c}\text { Mean number of nuclei in } \\
\text { blastocysts (no. } \pm \text { S.E.M.) }\end{array}$ \\
\hline FSH & 244 & $87.0 \pm 2.6^{\mathrm{a}}$ & $16.4 \pm 2.9^{\mathrm{a}}$ & $18.7 \pm 3.3^{\mathrm{a}}$ & $22.9 \pm 1.1^{\mathrm{a}}$ \\
FSH+LH & 246 & $87.8 \pm 2.4^{\mathrm{a}}$ & $17.6 \pm 2.7^{\mathrm{a}}$ & $19.8 \pm 4.6^{\mathrm{a}}$ & $23.1 \pm 1.0^{\mathrm{a}}$ \\
PMSG+hCG & 262 & $88.8 \pm 1.5^{\mathrm{a}}$ & $21.4 \pm 3.1^{\mathrm{a}}$ & $23.5 \pm 4.4^{\mathrm{a}}$ & $24.2 \pm 0.3^{\mathrm{a}}$ \\
AREG & 230 & $75.1 \pm 1.6^{\mathrm{b}}$ & $30.6 \pm 2.3^{\mathrm{b}}$ & $39.5 \pm 3.1^{\mathrm{b}}$ & $29.5 \pm 1.2^{\mathrm{b}}$ \\
\hline
\end{tabular}

Values with different superscripts within columns are significantly different $(P<0.05)$. The data were summarized from eight replicates.

The results of our study showed that EREG and AREG are markedly less efficient than FSH in stimulating resumption of meiosis in pig oocytes, leaving 30-45\% oocytes in GV stage. Consequently, the differences between FSH and the EGF-like peptides in stimulating maturation to MII stage may reflect the relative degree of meiotic resumption. Correspondingly with the results of our study, the EGF-like peptides were shown to stimulate maturation of pig COCs in vitro but they were less efficient than gonadotropins (eCG+hCG; Akaki et al. 2009). A reason of the lower potential of the EGF-like peptides to initiate resumption of meiosis in isolated pig COCs cannot be specified yet due to incomplete information about mechanisms involved in this process. We assume that the reason may lie in low level of cAMP in the AREG- and EREG-stimulated COCs, which may adversely affect function of the cumulus cells and also communication between the oocyte and the cumulus compartment. This assumption is supported by the finding that combination of the EGF-like peptides with dbcAMP during first $20 \mathrm{~h}$ of culture improved the results of maturation to the level observed with gonadotropins and IVF, and culture of such oocytes yielded blastocysts with full developmental competence (Akaki et al. 2009). In mouse preantral follicle culture model, EREG-induced incomplete mucification and expansion of the cumulus cells had a significantly lower effect than hCG/EGF on meiotic resumption and progesterone production (Romero \& Smitz 2009). However, in that study, EREG proved to be as capable as hCG/EGF in inducing both cumulus expansion and polar body formation in COCs isolated from fully-grown follicles and cultured in vitro.

A coordinated activation of several kinases in cumulus cells compartment is essential for induction of mammalian oocyte maturation and cumulus expansion. In the mouse, the PKA-driven activation of MAPK3/1 in cumulus cells appears essential for gonadotropininduced resumption of oocyte meiosis (Su et al. 2002, Fan et al. 2004, 2009). Moreover, the induction of cumulus expansion by FSH, EGF, 8-bromo-cAMP, and a growth differentiation factor 9 also required the participation of MAPK3/1 (Su et al. 2002). The cAMP/PKA signaling is involved in a transactivation of the EGF network in the mouse cumulus cell (Conti et al. 2006). In the pig, both phosphatidylinositol 3-kinase (PI3K) and MAPK activation in cumulus is required for gonadotropin-stimulated resumption of meiosis
(Shimada et al. 2001, Meinecke \& Krischek 2003, Liang et al. 2005). PI3K/AKT-dependent pathway was also involved in the promotion of $\mathrm{FSH}$-stimulated production of hyaluronic acid in pig COCs by insulinlike growth factor 1 (Nemcova et al. 2007). Therefore, in this study, we assessed the activation of PKA, MAPK, and AKT in the cumulus cells by FSH and EGF-like peptides and also the expression of the expansion-related genes. The present data indicate that FSH activates all of the studied kinases. AREG and EREG promptly activated MAPK3/1 and AKT pathway without any increase in PKA activity. Though both FSH and the EGF-like factors induced a rapid expression of the expansion-related genes, FSH was more efficient in this aspect, especially in the HAS2 and TNFAIP6 induction. The lower expression of expansion-related genes may be a reason of the inability of AREG- and EREG-stimulated COCs to maintain the expansion beyond $28 \mathrm{~h}$ of culture, as shown in our experiments. Thus, the failure of the EGRFlike peptides to activate PKA was not detrimental to acquisition of oocyte developmental competence, but may have affected the ability of the COCs to stabilize hyaluronic acid in expanding cumulus.

The disruption of progesterone receptor in granulosa cells of preovulatory follicles in vivo blocks ovulation and impacts a diverse set of the genes that control protease activity, cGMP signaling, exocytosis, and inflammation (Sriraman et al. 2010). However, the significance of progesterone and progesterone receptor signaling for maturation of mammalian oocytes in vitro is a matter of debate. The cultured COCs dramatically increase progesterone production following stimulation by gonadotropins (Jezova et al. 2001). However, the inhibition of steroidogenesis by ketoconazole did not affect maturation of rat oocytes in vitro (Tsafriri et al. 1998). In the pig, progesterone and progesterone receptor signaling appears important for maintenance of a proper cumulus cell function during the culture of COCs in vitro. Either progesterone synthesis inhibition or progesterone receptor antagonists impaired expansion of cumulus cell, resumption of meiosis, and the developmental competence of oocytes (Yamashita et al. 2003, Shimada et al. 2004). The molecular basis of the progesterone significance may consist in its essential role in induction and maintenance of TACE/ADAM17 expression that is indispensable for production of mature forms of AREG and EREG (Yamashita et al. 2010). 
Thus, the addition of mature forms of AREG and EREG to the culture medium may have bypassed the observed requirement of the pig COCs for the high progesterone concentration and resulted in production of high-quality oocytes in a low-progesterone environment in this study. In concert with our results, Romero \& Smitz (2009) also found EREG to be a poor stimulator of progesterone production in cultured follicles. Addition of progesterone to the EREG stimulus had no positive effect on maturation of the oocytes, indicating that low concentration of progesterone was not a cause of the weak effect of EREG on cumulus expansion and oocyte maturation in that study.

The results of this paper confirm a relatively high and consistent efficiency of parthenogenetic stimulation in inducing preimplantation development of pig oocytes. We have shown in this study that oocytes stimulated with AREG or EREG have lower maturation rate than those stimulated with FSH, and that the EGF-like peptides do not elicit all signals in the cumulus cells detected following gonadotropin stimulation. Despite these facts, we have repeatedly and consistently observed better development to blastocyst stage and higher blastocyst quality in groups of oocytes cultured with EGF-like peptides than in the groups cultured with gonadotropins only. Thus, the induction of EGF-like peptide synthesis in the cultured COCs by gonadotropins seems to be less efficient, at least for acquisition of the oocyte developmental capacity, than the usage of the mature forms of the peptides. So far, we do not know whether this is a matter of quantity of the peptides or quality of the downstream signaling or both. Alternatively, FSH may stimulate in isolated COCs a response detrimental to development. The explanation of these questions requires further studies about the mechanisms driving synthesis of EGF-like peptides in granulosa/cumulus cell and their engagement in a series of post-transcriptional events leading to resumption of meiosis in mammalian oocytes. Nevertheless, the blastocysts originated from AREG-treated COCs and transferred to recipients supported development to term (Akaki et al. 2009), indicating the capability of exogenous EGF-like peptides to induce a physiological mechanism leading to completion of meiosis and acquisition of full oocyte developmental competence.

In conclusion, we show in the present study that AREG and EREG are expressed in cultured pig COCs after gonadotropin stimulation, and the exogenous peptides may be effectively used for stimulation of pig oocyte maturation in vitro. The EGF-like peptides do not mimic all signals elicited in the cultured COCs by gonadotropins: they do not activate PKA in cumulus cells, do not stimulate expression of CYP11A1 and progesterone production, and are less efficient in increasing expression of the expansion genes. Despite these differences, they yield oocytes with superior developmental competence.

\section{Materials and Methods}

\section{Isolation and culture of COCs}

Ovaries of slaughtered gilts were collected at a local abattoir and transported to the laboratory in a thermos at $37^{\circ} \mathrm{C}$. The contents of the medium size follicles $(3-6 \mathrm{~mm}$ in diameter) were aspirated by using a syringe connected with a $20 \mathrm{G}$ needle, pooled in a Petri-dish, and diluted with PBS with $3 \mathrm{mg} / \mathrm{ml}$ polyvinylpyrrolidone (PVP). COCs were picked out from the aspirate and washed in the PVP-PBS. Only COCs surrounded by compact multi-layered cumulus were selected for experiments. About 30 COCs were cultured in $1 \mathrm{ml}$ of medium M-199 with Hanks' salt (M 7653, Sigma) supplemented with $0.91 \mathrm{mM}$ sodium pyruvate, $0.57 \mathrm{mM}$ cysteine, $1 \mathrm{mM}$ glutamine, $9 \mathrm{mM}$ sodium bicarbonate, $5.5 \mathrm{mM}$ HEPES, antibiotics, and $10 \%$ of FF or $5 \%$ of FCS in gene expression experiments. The COCs were cultured in 4-well dishes (Nunclon, Roskilde, Denmark) at $38.5^{\circ} \mathrm{C}$ in a humidified atmosphere of $5 \% \mathrm{CO}_{2}$ in the air. The maturation of oocytes and expansion of cumulus cells were stimulated by the addition of recombinant FSH (1 IU/ml; Gonal-f, Serono Europe), EGF-like peptides $(100 \mathrm{ng} / \mathrm{ml}$; EREG, R\&D Systems, Minneapolis, MN, USA; AREG, Sigma; BTC, Sigma), LH (1 IU/ml, Luveris, Serono), or PMSG/hCG $(10 / 5 \mathrm{IU} / \mathrm{ml}$, P.G. 600, Intervet, Boxmeer, The Netherlands) into the culture medium.

\section{Assessment of oocyte maturation and cumulus cell expansion}

To assess the nuclear maturation, oocytes were removed of cumulus cells by vortexing, mounted on slides, and fixed in acetic ethanol for $48 \mathrm{~h}$. Oocytes were then stained with $1 \%$ orcein and observed with a light microscope. Oocytes were scored for GV, GVBD, and for MII stage.

The degree of cumulus expansion was assessed at $24 \mathrm{~h}$ after the onset of culture using a subjective scoring method (Prochazka et al. 2000). Briefly, no response is scored as 0, minimum observable response, the cells in the outermost layer of the cumulus become round and glistening as 1 , the expansion of outer COCs layers as 2, the expansion of all COCs layers except corona radiata as 3, and the expansion of all COCs layers as 4.

\section{Activation of oocytes and culture of parthenogenetic embryos}

The COCs matured in M199 supplemented with 10\% of FF were freed of cumulus cells by hyaluronidase treatment $(1 \mathrm{mg} / \mathrm{ml})$, washed in PBS supplemented with $3 \mathrm{mg} / \mathrm{ml}$ of BSA (fraction V, Sigma), and activated by exposure to $10 \mu \mathrm{M}$ ionomycin (Sigma) in PBS for 5 min. They were then washed and cultured in medium PZM 3 (Yoshioka et al. 2002) supplemented with $4 \mathrm{mg} / \mathrm{ml}$ BSA and $2 \mathrm{mM}$ of 6-DMAP (Sigma) for $5 \mathrm{~h}$. The presumable parthenogenetic embryos were then washed and cultured in $1 \mathrm{ml}$ of medium PZM 3 without 6-DMAP in 4-well culture dishes (Nunclon) for 6 days at $38.5{ }^{\circ} \mathrm{C}$ under an atmosphere of $5 \% \mathrm{CO}_{2}$ in air. The number of cleaving embryos at two- or four-cell stage was assessed on day 2 , and the number of embryos that had reached blastocyst stage was assessed at the end of culture. An embryo with 


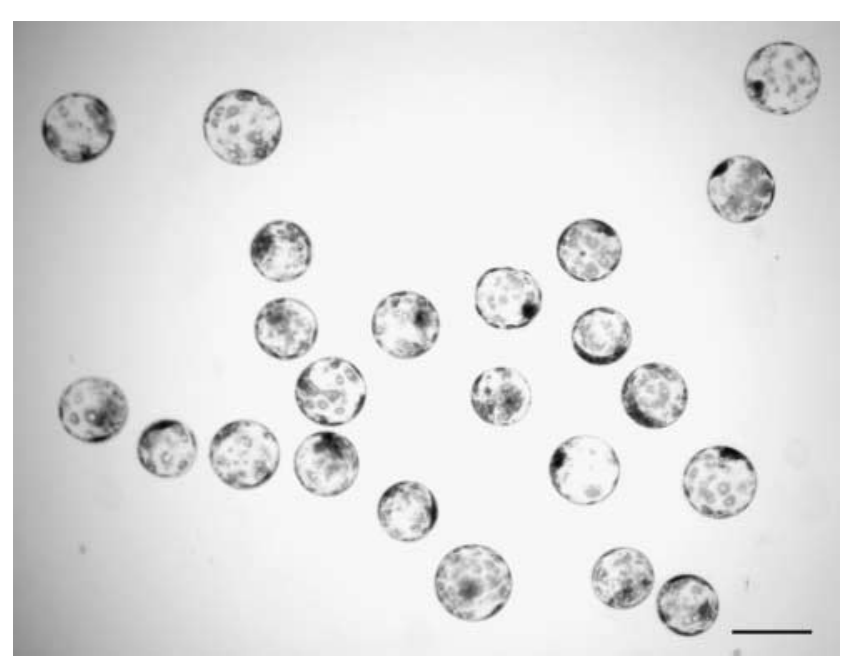

Figure 6 Set of parthenogenetic blastocysts produced in a single experiment from oocytes cultured in medium with AREG. Note the distinguishable inner cell mass and trophectoderm in the blastocysts. Bar $=200 \mu \mathrm{m}$.

a well-developed blastocoel cavity and a distinguishable embryoblast was scored as a blastocyst (Fig. 6).

\section{RNA isolation}

Total RNA from 30 COCs was extracted with the use of an RNeasy Mini kit (Qiagen) following the manufacturer's instructions. RNA was eluted in $50 \mu \mathrm{l}$ of RNase-free water and stored at $-80{ }^{\circ} \mathrm{C}$. The concentration of total RNA in samples was measured by a spectrophotometer NanoDrop ND-1000 (NanoDrop Technologies, Wilmington, DE, USA).

\section{Porcine BTC primer design, DNA sequencing, and data analysis}

By searching the pig-expressed sequence tag (EST) database using the BTC sequences of human (BC011618), primate
(XM_517223), and bovine (NM_173896), two porcine EST sequences (CB477123 and EW446187) were chosen for designing a pair of primers (Table 4, BTCseq), amplifying the porcine coding region of BTC. The amplification was performed on the PTC-2000 Thermal cycler (MJ Research, Waltham, MA, USA) by the use of a One-Step RT-PCR kit (Qiagen). Total RNA was reverse transcribed and subsequently amplified in a reaction mixture (total volume $25 \mu \mathrm{l}$ ) containing $5 \mu \mathrm{l} 5 \times$ reaction buffer, $1 \mu \mathrm{l}$ dNTP mix (10 mM stock of each), $0.5 \mu \mathrm{l}$ of both reverse and forward primers (0.02 $\mathrm{mM}$ stock), $0.15 \mu \mathrm{l}$ RNasine $(20 \mathrm{U} / \mu \mathrm{l}$ stock, Promega), $1 \mu \mathrm{l}$ enzyme mix, and RNA. The RT-PCR conditions were as follows: cDNA synthesis at $50{ }^{\circ} \mathrm{C}$ for $30 \mathrm{~min}$, pre-denaturation at $95^{\circ} \mathrm{C}$ for $15 \mathrm{~min}$, followed by $40 \mathrm{PCR}$ cycles consisting of denaturation $\left(95{ }^{\circ} \mathrm{C}\right.$ for $\left.30 \mathrm{~s}\right)$, annealing at $55^{\circ} \mathrm{C}(30 \mathrm{~s})$, extension $\left(72{ }^{\circ} \mathrm{C}\right.$ for $45 \mathrm{~s}$ ), and final extension at $72{ }^{\circ} \mathrm{C}$ for $5 \mathrm{~min}$. After the agarose gel electrophoresis, PCR product was isolated from the gel using the MinElute Gel Extraction kit (Qiagen) according to the manufacturer's instructions and sequenced using Big Dye Terminator kit V.3.1. (Applied Biosystems, Foster City, CA, USA) and ABI Prism 310 automated DNA sequencer (Applied Biosystems). The resulting sequences were identified using the basic local alignment search tool (BLAST; Altschul et al. 1990).

We amplified and sequenced the $1125 \mathrm{bp}$ fragment of partial porcine BTC. Comparing the obtained data using the BLAST, the sequence was 87,87 , and $79 \%$ homologous to human, primate, and bovine BTC respectively, based on published sequences (GenBank accession numbers BC011618, XM_517223 and NM_1738936), and shares the 100\% identity with Sus scrofa mRNA, expressed in alveolar macrophages (AK343801). The porcine partial mRNA sequence for BTC was deposited in the EMBL/GenBank/DDBJ database (accession number: FR694924).

\section{Real time RT-PCR}

The relative abundance of AREG, EREG, BTC, HAS2, TNFAIP6, PTGS2, and CYP11A1 mRNA in pig COCs was assessed by

Table 4 Primers used for real-time RT-PCR.

\begin{tabular}{|c|c|c|c|c|}
\hline $\begin{array}{l}\text { Gene } \\
\text { transcript }\end{array}$ & Primers & $\begin{array}{l}\text { Amplicon } \\
\text { length }(b p)\end{array}$ & $\mathbf{T}_{\text {an }}\left({ }^{\circ} \mathrm{C}\right)$ & $\begin{array}{l}\text { GenBank accession } \\
\text { number }\end{array}$ \\
\hline AREG & 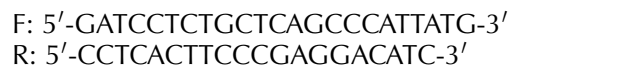 & 140 & 54 & NM_214376 \\
\hline EREG & $\begin{array}{l}\text { F: 5'-AAG ACA ATC CAG GTG TGG CTC AAG-3' } \\
\text { R: 5'-CGA TTT TTG TAC CAT CTG CAG AAA-3' }\end{array}$ & 276 & 58 & Yamashita et al. (2007) \\
\hline BTCseq & $\begin{array}{l}\text { F: 5'-CAC ATG GGA ATT CAA CCA GGA GC-3' } \\
\text { R: 5'-TAA CAC ATA TTC CAG GGC TCT GC-3' }\end{array}$ & 1125 & 55 & \\
\hline$B T C$ & $\begin{array}{l}\text { F: } 5^{\prime}-\mathrm{GCT} \text { GTC ATC CTC TTC GGA AA-3' } \\
\text { R: } 5^{\prime} \text {-AGG CAT TTT GTA GCT CGC AC-3' }\end{array}$ & 161 & 54 & FR694924 \\
\hline CYP11A1 & $\begin{array}{l}\text { F: 5'-TTC CAG AAG TAT GGT CCC ATT TA-3' } \\
\text { R: 5'-TGA GCA TGG GGA CAC TAG TGT GG-3' }\end{array}$ & 501 & 58 & NM_214427 \\
\hline HAS2 & $\begin{array}{l}\text { F: 5'-GAA GTC ATG GGC AGG GAC AAT TC-3' } \\
\text { R: 5'-TGG CAG GCC CTT TCT ATG TTA- } 3^{\prime}\end{array}$ & 407 & 54 & NM_214053 \\
\hline PTGS2 & $\begin{array}{l}\text { F: 5'-TCG ACC AGA GCA GAG AGA TGA GAT-3' } \\
\text { R: 5'-ACC ATA GAG CGC TTC TAA CTC TGC-3' }\end{array}$ & 260 & 55 & NM_214321 \\
\hline TNFAIP6 & $\begin{array}{l}\text { F: 5'-TCA TAA CTC CAT ATG GCT TGA AC- } 3^{\prime} \\
\text { R: 5'-TCT TCG TAC TCA TTT GGG AAG CC- } 3^{\prime}\end{array}$ & 396 & 54 & Yamashita et al. (2007) \\
\hline$A C T B$ & $\begin{array}{l}\text { F: 5'-GAG AAG CTC TGC TAC GTC G-3' } \\
\text { R: 5'-CCA GAC AGC ACC GTG TTG G-3' }\end{array}$ & 255 & 58 & U07786 \\
\hline
\end{tabular}

$\mathrm{T}_{\mathrm{an}}$, annealing temperature. 
a real-time RT-PCR using a One-Step RT-PCR kit (Qiagen) and primers designated for the specific sequences (Table 4). The reaction mixture was the same as described above. In addition, $0.5 \mu \mathrm{l}$ SYBR Green I of 1:1000× stock solution (Molecular Probes, Eugene, OR, USA) was added in each reaction. The amplification was performed on the RotorGene 3000 cycler (Corbett Research, Sydney, NSW, Australia). The reaction conditions were as follows: cDNA synthesis at $50{ }^{\circ} \mathrm{C}$ for $30 \mathrm{~min}$, pre-denaturation at $95^{\circ} \mathrm{C}$ for $15 \mathrm{~min}$, followed by various numbers of PCR cycles consisting of denaturation $\left(95^{\circ} \mathrm{C}\right.$ for $\left.15 \mathrm{~s}\right)$, annealing $(20 \mathrm{~s})$ at temperature specific for each set of primers (Table 4), extension $\left(72{ }^{\circ} \mathrm{C}\right.$ for $20 \mathrm{~s}$ ), and final extension at $72{ }^{\circ} \mathrm{C}$ for $5 \mathrm{~min}$. Fluorescence data were acquired during an additional step at $\sim 3{ }^{\circ} \mathrm{C}$ below the products melting temperature. After the cycling, the melting curve was generated to verify the amplification of one specific target (one peak at a specific melting temperature demonstrates the specificity). In addition, gel electrophoresis and ethidium bromide staining assessed the specificity of RT-PCR products.

The relative concentration of templates in different samples was determined using comparative analysis software (Corbett Research). The results for individual target messages were normalized according to the relative concentration of the internal standard, actin- $\beta(A C T B)$.

\section{PKA activity assay}

PKA activity was assessed by a PepTag Assay for NonRadioactive Detection of cAMP-Dependent Protein Kinase kit (Promega) according to the manufacturer's instructions. Briefly, 50 COCs were cultured for $1.5 \mathrm{~h}$ and then stored frozen at $-70{ }^{\circ} \mathrm{C}$ in a minimum volume of PBS until use in the assay. The samples were lysed in $10 \mu \mathrm{l}$ of cell lysis buffer (Cell Signaling Technology, Danvers, MA, USA) and mixed in a test tube with $5 \mu \mathrm{l}$ of PKA reaction buffer $(100 \mathrm{mM}$ Tris, $\mathrm{pH} 7.4,50 \mathrm{mM}$ $\mathrm{MgCl}_{2}$, and $5 \mathrm{mM} \mathrm{ATP),} 5 \mu \mathrm{l}$ of PKA-specific fluorescent peptide substrate (Kemptide, $0.4 \mu \mathrm{g} / \mu \mathrm{l}$ stock), and $5 \mu \mathrm{l}$ of deionized water. Negative control assay was run without the cell sample; in positive control assays, the sample was substituted with $25 \mathrm{ng}$ of catalytic subunit of PKA (diluted in $5 \mu \mathrm{l}$ of $350 \mathrm{mM} \mathrm{K}_{3} \mathrm{PO}_{4}$ with $0.1 \mathrm{mM}$ dithiothreitol) and $5 \mu \mathrm{l}$ of PKA activator solution ( $5 \mu \mathrm{M}$ cAMP in water). The reaction mixture was incubated at room temperature for $30 \mathrm{~min}$ and then stopped by placing the test tubes in boiling water for $10 \mathrm{~min}$. The samples were loaded into the wells in $0.8 \%$ agarose gel and run at $100 \mathrm{~V}$ for $15 \mathrm{~min}$. The phosphorylated substrate migrated toward the positive electrode, while the non-phosphorylated substrate migrated toward the negative electrode. The gel was photographed in u.v. light, and the images were assessed for the proportions of phosphorylated and non-phosphorylated substrate by densitometry.

\section{Immunoblotting}

Groups of COCs were cultured in control or FSH-, AREG-, or EREG-supplemented medium for $1 \mathrm{~h}$ for AKT- or $2 \mathrm{~h}$ for MAPK3/1-detection and then lysed in $15 \mu$ of Laemmli sample buffer for SDS-PAGE, heated at $100{ }^{\circ} \mathrm{C}$ for $3 \mathrm{~min}$, and stored at $-80{ }^{\circ} \mathrm{C}$. The proteins of the samples were separated on $12 \%$ polyacrylamide gel and transferred to PVDF membrane (Immobilon-P, Millipore, Bedford, MA, USA). Membranes were blocked in 5\% low fat dry milk in Tris-buffered saline (TBS) with $0.5 \%$ of Tween 20 for $2 \mathrm{~h}$ at room temperature and then incubated with primary antibody diluted $1: 2000$ in $5 \%$ BSA in TBS-Tween, at $4{ }^{\circ} \mathrm{C}$ overnight. The following primary antibodies were used: phospho-AKT (Ser 473); AKT - both from Cell Signaling Technology; p-ERK; ERK (detecting MAPK3/1) both from Santa Cruz Biotechnology (Santa Cruz, CA, USA). The secondary antibody (anti-mouse or anti-rabbit IgG conjugated with HRP; Amersham) was diluted 1:5000 in 2\% BSA in TBS-Tween. The membranes were incubated with the secondary antibody for $1 \mathrm{~h}$ at room temperature and washed intensively in TBS-Tween. The immune reaction was detected by ECL (Pierce, Rockford, IL, USA) according to the manufacturer's instructions. Following detection, the antibodies were stripped by incubation of the membrane in $25 \mathrm{mM}$ Tris with $2 \%$ $\beta$-mercaptoethanol and $0.2 \%$ SDS at $60{ }^{\circ} \mathrm{C}$ for $20 \mathrm{~min}$ and re-probed with the next primary antibody. The intensity of the specific bands on the blots was analyzed by scanning densitometry using Image J Version 1.29 free software (National Institute of Mental Health, Bethesda, MD, USA).

\section{Progesterone assay}

To assess production of progesterone by the cumulus cells, 20-30 COCs were cultured in $300 \mu$ of control, FSH, AREG, or EREG supplemented medium for $44 \mathrm{~h}$. At the end of the incubation period, the cultured media were collected for progesterone RIA determination kit (Institute of Isotopes, Budapest, Hungary). The concentration of progesterone found in culture medium and related to ten COCs. The crossreactivity of the progesterone antibody was $<13 \%$ with other progestins, and $<0.01 \%$ with the androgens and estrogens tested. The intra- and inter-assay coefficients of variation were $\leq 10.2$ and $11.8 \%$ respectively.

\section{Statistical analysis}

Each experiment was carried out in at least three replicates. Each replicate was performed on different days on a single batch of COCs that were randomly allocated to the treatments. The differences in percentages of maturing oocytes, expanding COCs, cleaving embryos and blastocysts, and the quantifications of RT-PCR results and progesterone levels were compared by the ANOVA followed by Tukey's post-test. Error bars indicate the S.E.M.

\section{Declaration of interest}

The authors declare that there is no conflict of interest that could be perceived as prejudicing the impartiality of the research reported.

\section{Funding}

This work was supported by Institutional Research Project (AV0Z50450515), Grant Agency of the Czech Republic 
(grant 523/08/0111), and Ministry of Agriculture of the Czech Republic (grant QI 101A166).

\section{Acknowledgements}

The authors would like to thank Drs S Scsuková and A Mlynarčíková for measurement of progesterone concentration.

\section{References}

Akaki Y, Yoshioka K, Noguchi M, Hoshi H \& Funahashi H 2009 Successful piglet production in a chemically defined system for in vitro production of porcine embryos: dibutyryl cyclic AMP and epidermal growth factorfamily peptides support in vitro maturation of oocytes in the absence of gonadotropins. Journal of Reproduction and Development 55 446-453. (doi:10.1262/jrd.20219)

Altschul SF, Gish W, Miller W, Myers EW \& Lipman DJ 1990 Basic local alignment search tool. Journal of Molecular Biology 215 403-410. (doi:10.1016/S0022-2836(05)80360-2)

Ashkenazi H, Cao X, Motola S, Popliker M, Conti M \& Tsafriri A 2005 Epidermal growth factor family members: endogenous mediators of the ovulatory response. Endocrinology 146 77-84. (doi:10.1210/en.20040588)

Ben-Ami I, Freimann S, Armon L, Dantes A, Strassburger D, Friedler S, Raziel A, Seger R, Ron-El R \& Amsterdam A 2006 PGE $_{2}$ up-regulates EGF-like growth factor biosynthesis in human granulosa cells: new insights into the coordination between $\mathrm{PGE}_{2}$ and $\mathrm{LH}$ in ovulation. Molecular Human Reproduction 12 593-599. (doi:10.1093/molehr/ gal068)

Conti M, Hsieh M, Park JY \& Su YQ 2006 Role of the epidermal growth factor network in ovarian follicles. Molecular Endocrinology 20 715-723. (doi:10.1210/me.2005-0185)

Downs SM \& Chen J 2008 EGF-like peptides mediate FSH-induced maturation of cumulus cell-enclosed mouse oocytes. Molecular Reproduction and Development 75 105-114. (doi:10.1002/mrd.20781)

Fan HY, Huo LJ, Chen DY, Schatten H \& Sun QY 2004 Protein kinase C and mitogen-activated protein kinase cascade in mouse cumulus cells: cross talk and effect on meiotic resumption of oocyte. Biology of Reproduction 70 1178-1187. (doi:10.1095/biolreprod.103.024737)

Fan HY, Liu Z, Shimada M, Sterneck E, Johnson PF, Hedrick SM \& Richards JS 2009 MAPK3/1(ERK1/2) in ovarian granulosa cells are essential for female fertility. Science 324 938-941. (doi:10.1126/science. 1171396)

Freimann S, Ben-Ami I, Dantes A, Ron-El R \& Amsterdam A 2004 EGF-like factor epiregulin and amphiregulin expression is regulated by gonadotropins/cAMP in human ovarian follicular cells. Biochemical and Biophysical Research Communications 324 829-834. (doi:10.1016/j. bbrc.2004.09.129)

Fru KN, Cherian-Shaw M, Puttabyatappa M, VandeVoort CA \& Chaffin CL 2007 Regulation of granulosa cell proliferation and EGF-like ligands during the periovulatory interval in monkeys. Human Reproduction 22 1247-1252. (doi:10.1093/humrep/del519)

Jezova M, Scsukova S, Nagyova E, Vranova J, Prochazka R \& Kolena J 2001 Effect of intraovarian factors on porcine follicular cells: cumulus expansion, granulose and cumulus cell progesterone production. Animal Reproduction Science 65 115-126. (doi:10.1016/S0378-4320 (00)00219-0)

Kaufman MH \& Gardner RL 1974 Diploid and haploid mouse parthenogenetic development following in vitro activation and embryo transfer. Journal of Embryology and Experimental Morphology 31 635-642.

Kawashima I, Okazaki T, Noma N, Nishibori M, Yamashita Y \& Shimada M 2008 Sequential exposure of porcine cumulus cells to $\mathrm{FSH}$ and/or $\mathrm{LH}$ is critical for appropriate expression of steroidogenic and ovulation-related genes that impact oocyte maturation in vivo and in vitro. Reproduction 136 9-21. (doi:10.1530/REP-08-0074)

Liang CG, Huo LJ, Zhong ZS, Chen DY, Schatten H \& Sun QY 2005 Cyclic adenosine $3^{\prime}, 5^{\prime}$-monophosphate-dependent activation of mitogen-activated protein kinase in cumulus cells is essential for germinal vesicle breakdown of porcine cumulus-enclosed oocytes. Endocrinology 146 4437-4444. (doi:10.1210/en.2005-0309)

Lindbloom SM, Farmerie TA, Clay CM, Seidel GE Jr \& Carnevale EM 2008 Potential involvement of EGF-like growth factors and phosphodiesterases in initiation of equine oocyte maturation. Animal Reproduction Science 103 187-192. (doi:10.1016/j.anireprosci.2007. 04.006)

Meinecke B \& Krischek C 2003 MAPK/ERK kinase (MEK) signalling is required for resumption of meiosis in cultured cumulus-enclosed pig oocytes. Zygote 11 7-16. (doi:10.1017/S0967199403001023)

Nemcova L, Nagyova E, Petlach M, Tomanek M \& Prochazka R 2007 Molecular mechanisms of insulin-like growth factor 1 promoted synthesis and retention of hyaluronic acid in porcine oocyte-cumulus complexes. Biology of Reproduction 76 1016-1024. (doi:10.1095/ biolreprod.106.057927)

Park JY, Su YQ, Ariga M, Law E, Jin SL \& Conti M 2004 EGF-like growth factors as mediators of LH action in the ovulatory follicle. Science $\mathbf{3 0 3}$ 682-684. (doi:10.1126/science.1092463)

Prochazka R, Srsen V, Nagyova E, Miyano T \& Flechon JE 2000 Developmental regulation of effect of epidermal growth factor on porcine oocyte-cumulus cell complexes: nuclear maturation, expansion, and F-actin remodeling. Molecular Reproduction and Development 56 63-73. (doi:10.1002/(SICl)1098-2795(200005)56:1 <63::AID-MRD8> 3.0.CO;2-D)

Prochazka R, Kalab P \& Nagyova E 2003 Epidermal growth factor-receptor tyrosine kinase activity regulates expansion of porcine oocyte-cumulus cell-complexes in vitro. Biology of Reproduction 68 797-803. (doi:10. 1095/biolreprod.102.005520)

Prochazka R, Nemcova L, Nagyova E, Scsukova S \& Mlynarcikova A 2009 Development of functional LH receptors on pig cumulus-oocyte complexes cultured in vitro by a novel two-step culture system. Molecular Reproduction and Development 76 751-761. (doi:10.1002/ $\operatorname{mrd}$.21039)

Roh S \& Hwang WS 2002 In vitro development of porcine parthenogenetic and cloned embryos: comparison of oocyte-activating techniques, various culture systems and nuclear transfer methods. Reproduction, Fertility, and Development 14 93-99. (doi:10.1071/RD01090)

Romero S \& Smitz J 2009 Epiregulin can effectively mature isolated cumulus-oocyte complexes, but fails as a substitute for the hCG/ epidermal growth factor stimulus on cultured follicles. Reproduction $\mathbf{1 3 7}$ 997-1005. (doi:10.1530/REP-08-0523)

Shimada M, Maeda T \& Terada T 2001 Dynamic changes of connexin-43, gap junctional protein, in outer layers of cumulus cells are regulated by PKC and PI3-kinase during meiotic resumption in porcine oocytes. Biology of Reproduction 64 1255-1263. (doi:10.1095/biolreprod64.4. 1255)

Shimada M, Yamashita Y, Ito J, Okazaki T, Kawahata K \& Nishibori M 2004 Expression of two progesterone receptor isoforms in cumulus cells and their roles during meiotic resumption of porcine oocytes. Journal of Molecular Endocrinology 33 209-225. (doi:10.1677/jme.0.0330209)

Shimada M, Hernandez-Gonzalez I, Gonzalez-Robayna I \& Richards JS 2006 Paracrine and autocrine regulation of epidermal growth factor-like factors in cumulus oocyte complexes and granulosa cells: key roles for prostaglandin synthase 2 and progesterone receptor. Molecular Endocrinology 20 1352-1365. (doi:10.1210/me.2005-0504)

Sriraman V, Sinha M \& Richards JS 2010 Progesterone receptor-induced gene expression in primary mouse granulosa cell cultures. Biology of Reproduction 82 402-412. (doi:10.1095/biolreprod.109.077610)

Su YQ, Wigglesworth K, Pendola FL, O'Brien MJ \& Eppig JJ 2002 Mitogenactivated protein kinase activity in cumulus cells is essential for gonadotropin-induced oocyte meiotic resumption and cumulus expansion in the mouse. Endocrinology 143 2221-2232. (doi:10.1210/en.143. 6.2221)

Surani MA \& Barton SC 1983 Development of gynogenetic eggs in the mouse: implications for parthenogenetic embryos. Science $\mathbf{2 2 2}$ 1034-1036. (doi:10.1126/science.6648518)

Tsafriri A, Popliker M, Nahum R \& Beyth Y 1998 Effects of ketoconazole on ovulatory changes in the rat: implications on the role of a meiosisactivating sterol. Molecular Human Reproduction 4 483-489. (doi:10. 1093/molehr/4.5.483) 
Yamashita Y, Shimada M, Okazaki T, Maeda T \& Terada T 2003 Production of progesterone from de novo-synthesized cholesterol in cumulus cells and its physiological role during meiotic resumption of porcine oocytes. Biology of Reproduction 68 1193-1198. (doi:10.1095/biolreprod.102. 010934)

Yamashita Y, Kawashima I, Yanai Y, Nishibori M, Richards JS \& Shimada M 2007 Hormone-induced expression of tumor necrosis factor $\alpha$-converting enzyme/A disintegrin and metalloprotease-17 impacts porcine cumulus cell oocyte complex expansion and meiotic maturation via ligand activation of the epidermal growth factor receptor. Endocrinology 148 6164-6175. (doi:10.1210/en.2007-0195)

Yamashita Y, Kawashima I, Gunji Y, Hishinuma M \& Shimada M 2010 Progesterone is essential for maintenance of Tace/Adam17 mRNA expression, but not EGF-like factor, in cumulus cells, which enhances the EGF receptor signaling pathway during in vitro maturation of porcine COCs. Journal of Reproduction and Development 56 315-323. (doi:10. 1262/jrd.09-199H)

Yoshioka K, Suzuki C, Tanaka A, Anas IM \& Iwamura S 2002 Birth of piglets derived from porcine zygotes cultured in a chemically defined medium. Biology of Reproduction 66 112-119. (doi:10.1095/biolreprod66.1.112)

Received 7 October 2010

First decision 26 November 2010

Revised manuscript received 10 December 2010

Accepted 14 January 2011 